\title{
Proses Pemecahan Masalah Sistem Persamaan Linear Dua Variabel Berdasarkan Tahapan Mason Ditinjau dari Tipe Adversity Quotient
}

\author{
Novi Nurhayati ${ }^{1}$, Subanji ${ }^{2}$, Swasono Rahardjo ${ }^{3}$ \\ 1,2,3 Pascasarjana S2 Pendidikan Matematika, Fakultas Matematika dan Ilmu Pengetahuan Alam, Universitas Negeri Malang, \\ Jl. Semarang No.5, Malang, Jawa Timur, Indonesia \\ nurhayatinovi151196@gmail.com
}

\begin{abstract}
This study aims to describe the mathematical problem-solving process of a two-variable linear equation system based on Mason's stages in terms of the adversity quotient (AQ) type. Descriptive research with data collection techniques based on Adversity Response Profile (ARP) questionnaires was carried out at MTs Negeri 1 Kota Bima on 119 students in class IX. The research selected in this study considers students who have high AQ (climber), medium AQ (camper) and low AQ (quitter) levels based on the ARP questionnaire. The instruments used are questionnaires, test sheets and interviews. To describe qualitatively, 6 students were taken based on each Adversity Quotient category with teacher recommendations and students' willingness to be research subjects. The results of this study indicate that in the problem-solving process students are based on Mason stages, where students can fulfill all Mason stages: entry, attack, and review. Camper students only meet the entry and attack stages. Meanwhile, quitter students have not been able to fulfill all aspects of entry, attack, and review.
\end{abstract}

Keywords: Problem Solving Process, Two Variable Linear Equation System, Mason Stages, Adversity Quotient

\begin{abstract}
Abstrak
Penelitian ini bertujuan untuk mendeskripsikan proses pemecahan masalah matematika sistem persamaan linear dua variabel berdasarkan tahapan Mason ditinjau dari tipe adversity quotient $(A Q)$. Penelitian deskriptif dengan teknik pengambilan data berdasarkan angket Adversity Response Profile (ARP) dilaksanakan di MTs Negeri 1 Kota Bima pada 119 siswa kelas IX. Penelitian yang dipilih dalam penelitian ini mempertimbangkan siswa yang memiliki tingkat $A Q$ tinggi (climber), $A Q$ sedang (camper) dan $A Q$ rendah (quitter) berdasarkan angket ARP. Instrument yang digunakan adalah angket, lembar tes dan wawancara. Untuk mendeskripsikan secara kualitatif maka diambil 6 siswa yang diambil masing-masing 2 siswa berdasarkan setiap kategori Adversity Quotient dengan rekomendasi guru dan kesediaan siswa menjadi subjek penelitian. Hasil penelitian ini menunjukkan bahwa dalam proses pemecahan masalah siswa berdasarkan tahapan Mason, dimana siswa dapat memenuhi semua tahapan Mason: entry, attack, dan review. Untuk siswa camper hanya memenuhi tahapan entry dan attack saja. Sedangkan siswa quitter belum mampu memenuhi semua aspek entry, attack, dan review.
\end{abstract}

Kata Kunci: Proses Pemecahan Masalah, SPLDV, Tahapan Mason, Adversity Quotient

$\triangle$ Corresponding author: Novi Nurhayati

Email Address: nurhayatinovi151196@gmail.com (Jl. Semarang No.5, Malang, Jawa Timur, Indonesia)

Received 27 December 2021, Accepted 26 January 2022, Published 04 February 2022

\section{PENDAHULUAN}

Salah satu mata pelajaran yang memegang peranan penting dalam pendidikan adalah matematika. Pembelajaran matematika merupakan bagian integral dari pendidikan nasional, memegang peran penting bagi perkembangan ilmu dan teknologi (Susanto, 2015). Peran matematika dalam memenuhi kebutuhan saat ini adalah mengarahkan pembelajaran pada pemahaman konsep dan menghubungkan ide-ide untuk menyelesaikan masalah matematika. Sedangkan di masa yang akan datang, yakni memberikan kemampuan berpikir logis, sistematis, kritis, dan cermat (Harahap et al., 2012). Hal ini sangat membantu siswa dalam menghadapi perkembangan zaman yang selalu berubah, tidak pasti, dan kompetitif yakni dengan mampu memperoleh, mengelola, dan memanfaatkan informasi (Fauzi \& Noviartati, 2018). Perubahan pada kurikulum 2013 salah satunya adalah materi 
pembelajaran sudah mencapai ranah metakognitif yang menuntut siswa mampu memprediksi, mendesain dan memperkirakan. Sehingga, siswa dituntut untuk menggunakan pengetahuan, pengalaman dan keterampilannya dalam proses menyelesaikan masalah (Suarsana et al., 2019).

Pemecahan masalah merupakan indikator penting yang mendasar dalam pembelajaran matematika (Şimşek et al., 2020; Bailey, 2017; Jiang et al., 2021; Santos-Trigo, 2020). Sehingga fokus dari pembelajaran matematika adalah proses pemecahan masalah. Dalam pembelajaran matematika siswa tidak hanya dapat menjawab soal, tetapi strategi proses pemecahan masalah untuk mendapatkan solusi (Gözde, 2020). Dengan demikian salah satu tujuan pembelajaran matematika adalah memecahkan masalah yang meliputi kemampuan memahami masalah, merancang model matematika, memecahkan model matematika, dan menafsirkan solusi yang diperoleh (Depdiknas, 2006). Hal ini dikarenakan dalam memecahkan soal pemecahan masalah diperlukan langkah atau strategi yang baru dan berbeda dibandingkan dengan langkah atau strategi dalam memecahkan soal yang rutin atau biasa untuk menemukan solusi dalam pemecahan masalah (Barham, 2020).

Pemecahan masalah seseorang dituntut untuk berpikir secara sistematis, kritis, logis, serta memiliki sikap pantang menyerah untuk menemukan solusi dari masalah yang dihadapi (Karatas \& Baki, 2013). Anderson (2009) mendefinisikan pemecahan masalah sebagai suatu keterampilan individu dalam menganalisis, menafsirkan, menalar, memprediksi, mengevaluasi, dan merefleksikan. Sementara menurut (Maimunah et al., 2016) menyatakan bahwa pemecahan masalah ialah aktivitas intelektual guna menemukan solusi penyelesaian dari masalah dengan melibatkan pengetahuan dan pengalaman. Lebih lanjut, pemecahan masalah sebagai proses berfikir tingkat tinggi dalam matematika yang memerlukan pemahaman dan pengetahua yang memadai untuk dapat menemukan solusi yang tepat (Adnyani et al., 2018; Sari et al., 2019). Dengan memecahkan masalah, maka siswa akan berusaha menemukan solusi yang tepat menurut caranya sendiri guna menyelesaikan masalah tersebut.

Pemecahan masalah dapat diartikan sebagai upaya untuk mencari jalan keluar dari suatu masalah yang sukar dan penuh rintangan untuk mencapai solusi yang tepat (Polya, 1981). Sedangkan pemecahan masalah juga merupakan suatu cara mengorganisasi pengetahuan dan representasi pengetahuan secara simbolik di dalam ingatan jangka panjang (Reif \& Heller, 1982). Sehingga dapat disimpulkan bahwa memecahkan masalah merupakan suatu proses menentukan kombinasi aturanaturan dan pengetahuan yang telah dipelajari untuk digunakan dalam menyelesaikan masalah baru yang ditemui dalam kehidupan sehari-hari. Pendapat lain mengatakan bahwa dengan adanya pemecahan masalah siswa dapat mengetahui pemahaman konseptual siswa yang telah dipelajari (Gok, 2014).

Proses pemecahan masalah siswa dapat ditelusuri dengan berbagai kajian. Salah satu proses pemecahan masalah matematika adalah fase atau tahapan yang diungkapkan oleh Mason et al (2010). Adapun fase-fase atau tahapan tersebut adalah fase entry, attack, dan review. Rubrik yang terdapat pada fase entry adalah know, want, dan introduce. Rubrik yang terdapat pada fase attack adalah try, 
Proses Pemecahan Masalah Sistem Persamaan Linear Dua Variabel Berdasarkan Tahapan Mason Ditinjau dari Tipe Adversity Quotient, Novi Nurhayati, Subanji, Swasono Rahardjo

maybe, dan why. Rubrik yang terdapat pada fase review adalah check, reflect, dan extend. Pada tahapan atau fase pemecahan masalah entry, attack, dan review terdapat proses penting dalam penyelesaian masalah. Empat proses penting tersebut adalah specializing, generalizing, conjecturing, dan convincing (Mason et al., 2010). Specializing merupakan tahap mengkhususkan masalah seperti membuat suatu pola atau gambar dan menyusun bagian-bagian soal seperti apa yang diketahui dan apa yang ditanyakan. Generalizing merupakan kegiatan mencari langkah-langkah penyelesaian dan bagaimana menguji langkah-langkah kebenaran atas dugaan penyelesaian yang telah dibuat. Conjecturing merupakan kegiatan membuat dugaan dari pola yang telah dibuat. Dugaan yang telah dibuat diuji kebenarannya dan jika dugaan tersebut salah, maka harus dibuat dugaan baru sampai menemukan solusi yang tepat. Convincing merupakan kegiatan menjelaskan alasan penyelesaian berdasarkan konsep-konsep matematika.

Pada hasil observasi awal yang dilakukan dikelas VIII MTs Negeri 1 Kota Bima, kemampuan proses pemecahan siswa rendah, karena siswa sebagain besar tidak dapat menyelesaikan permasalahan yang berikan yang ditunjukan dari hasil jawaban siswa. Kondisi ini ditujukkan pada data pembagian soal tes observasi satu soal materi sistem persamaan linear dua variabel untuk melihat proses pemecahan masalah siswa. Dari observasi tersebut secara keseluruhan memberikan gambaran bahwa masih ada masalah dalam proses pemecahan masalah siswa. Sehingga, kemampuan proses pemecahan masalah belum benar-benar sesuai dengan yang diharapkan. Oleh karena itu keterampilan dan pengetahuan matematika sangat membantu siswa mengungkapkan proses dalam menyelesaikan masalah matematika (Yulaelawati, 2004). Sehingga sangat diperlukan pengetahuan atau keterampilan dalam pemecahan masalah agar tidak terdapat kesalahan-kesalahan. Kesalahan yang dilakukan oleh siswa tersebut dapat dijadikan sumber informasi bagi guru untuk dapat merancang pembelajaran yang sesuai untuk meningkatkan proses pemecahan masalah siswa.

Pada penelitian yang dilakukan oleh (Wahyudi \& Dewi, 2016) kemampuan siswa dalam memecahkan masalah berupa penyelesaian soal-soal cerita masih rendah. Siswa cenderung lebih mudah menyelesaikan soal matematika yang hanya menerapkan rumus-rumus saja tanpa harus membaca soal cerita. Kemampuan siswa dalam memecahkan masalah secara runtut menggunakan konsep matematika berkaitan erat dengan kemampuan siswa. Selain itu, dikelas guru dihadapkan pada berbagai jenis perbedaan siswa dalam menyelesaikan masalah matematika (Cai, 2003). Salah satu faktor yang mempengaruhinya adalah Adversity Quotient (Stoltz, 2000). Stoltz menjelaskan bahwa Adversity Quotient adalah kemampuan seseorang dalam bertahan mengatasi kesulitan, mampu mengatasi kesulitan, dan mampu melampaui semua harapan atas usaha dan potensinya. Adversity Quotient dapat memprediksi dan mempengaruhi semua aspek kapasitas dan kinerja seseorang (Chin \& Hung, 2013) dan Adversity Quotient dapat menentukan tingkat keberhasilan atau kegagalan seseorang (Bautista, 2015).

Adversity Quotient terdiri dari 3 tipe, yaitu climber (tinggi), camper (sedang), dan quitter (rendah). Seorang dengan climber mampu menghadapi masalah atau menyelesaikan suatu 
permasalahan yang diberikan (MZ et al., 2017; Parvathy \& M, 2014; Phoolka \& Kaur, 2012). Pada camper adalah kecendurungan sesorang yang mempunyai keinginan untuk menyelesaikan suatu permasalahan, tetapi kurang teliti dalam menyelesaikan dan merasa cepat puas dengan apa yang didapatkannya (Phoolka \& Kaur, 2012). Sedangkan quitter merupakan kecenderungan seseorang yang mudah putus asa pada suatu permasalahan yang diberikan dan tidak memiliki keinginan untuk menyelesaikannya (Stoltz, 2000).

Pentingnya proses pemacahan masalah yang harus dikuasai siswa dalam pembelajaran matematika. Dimana materi persamaan linear dua variabel merupakan salah satu kompetensi dasar yang harus dikuasai dan dipahami oleh siswa. Materi tersebut merupakan pengetahuan awal yang harus dikuasai siswa untuk menuju pada materi selanjutnya dan harus dikuasai oleh siswa (Agustini \& Pujiastuti, 2020). Pada materi ini juga siswa akan belajar untuk menganalisis suatu permasalahan lalu membuat strategi pemecahan masalah tersebut dengan memodelkan permasalahan tersebut untuk mencari solusi yang dibutuhkan. Semua itu membutuhkan imajinasi, pemahaman dan pengetahuan dalam setiap pemecahan masalahnya (Febriana, 2018). Berdasarkan latar belakang yang telah dipaparkan, perlu penelitian lebih lanjut mengenai bagaimana proses pemecahan masalah matematika sistem persamaan linear dua variabel ditinjau dari tipe adversity quotient. Mengetahui proses pemecahan masalah siswa dalam pembelajaran

\section{METODE}

Penelitian ini bertujuan untuk mendeskripsikan proses pemecahan masalah matematika sistem persamaan linear dua variabel ditinjau dari tipe adversity quotient. Penelitian dilakukan pada populasi 119 siswa kelas IX terdiri dari empat kelas di MTs Negeri 1 Kota Bima dengan diberikan angket adversity quotient. Kemudian hasil angket dianalisis dengan memilih masing-masing dua sampel/subjek pada ketegori adversity quotient. Subjek dipilih dari 6 siswa berdasarkan kategori Adversity Quotient, dimana terdapat masing-masing 2 siswa tipe climber, camper dan quitter. Kemudian diberikan lembar tes pemecahan masalah matematika sistem persamaan linear dua variabel.

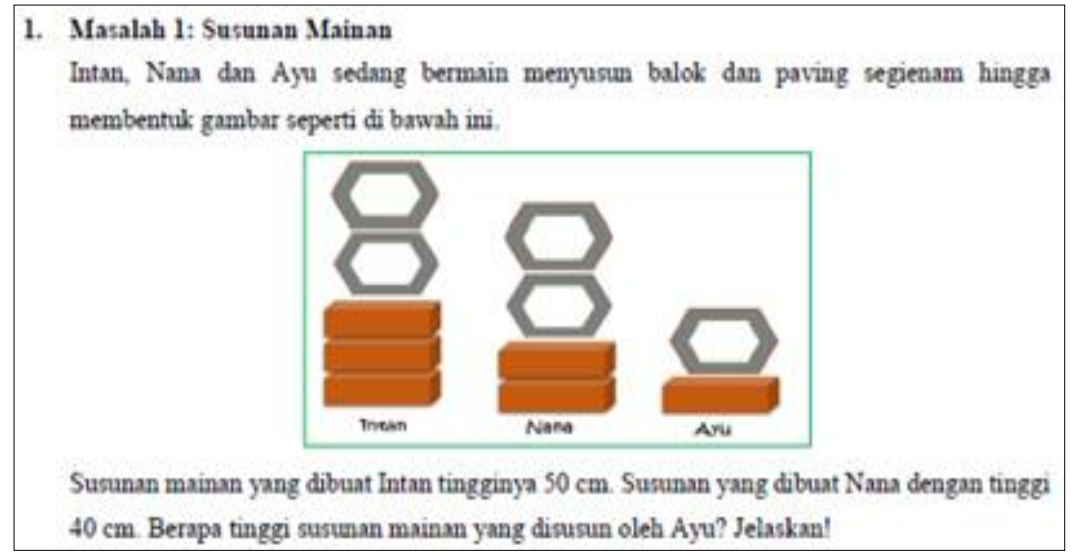

Gambar 1. Soal Tes 
Proses Pemecahan Masalah Sistem Persamaan Linear Dua Variabel Berdasarkan Tahapan Mason Ditinjau dari Tipe Adversity Quotient, Novi Nurhayati, Subanji, Swasono Rahardjo

Hasil tes kemudian dianalisis dengan menggunakan tahapan pemecahan masalah menurut Mason, Burton, \& Stacey (2010) dapat dilakukan melalui 3 fase berikut: (1) fase entry, dimulai ketika pertama kali menghadapi pertanyaan dan berakhir ketika telah memulai untuk mencoba menyelesaikannya. Rubrik yang terdapat pada fase ini ialah (a) know adalah memahami masalah dengan seksama (K1); (b) want adalah mengklasifikasikan dan menyaring informasi (W1) dan menentukan apa yang ditanyakan pada masalah (W2) dan; (3) introduce adalah merepresentasikan elemen-elemen penting dalam bentuk gambar, diagram, simbol dan tabel dan menyusun apa yang diketahui pada masalah (I1).

Pada fase attack, dilakukan dengan mengambil beberapa pendekatan yang dapat digunakan untuk menyelesaikan masalah. Rubrik yang terdapat pada fase ini ialah (a) try adalah mengajukan dugaan penyelesaian masalah (T1) (2) maybe adalah Mencoba dugaan yang telah dibuat untuk menyelesaiakan masalah (M2) dan; (3) why adalah mengomunikasikan alasan tersebut untuk menyakinkan orang lain baik lisan maupun tulisan dengan penyajikan penyelesaian masalah secara sistematis (H1). Sedangkan (3) fase review, dilakukan dengan pengecekan ulang atas penyelesain masalah yang telah dikerjakan dan merefleksi hal yang telah dilakukan. Rubrik yang terdapat pada tahap ini ialah (1) check adalah mengecek ketepatan perhitungan (C1) dan mengecek kesesuaian langkah penyelesaian dengan pertanyaan (C2); (b) reflect adalah merefleksikan ide dalam penyelesaian, bagian mana yang sulit dan apa yang dapat dipelajari dari penyelesaian yang dilakukan (R1), dan (3) extend adalah mencoba menyelesaikan masalah serupa dengan perubahan pada hal yang diketahui dan ditanyakan (E1).

\section{HASIL DAN DISKUSI}

Pemecahan masalah siswa diambil dari hasil tes yang dilakukan pada 6 siswa kelas IX yang telah mempelajari materi sistem persamaan linear dua variabel berdasarkan tiap kategori adversity quotient yang terdiri dari camper, climber, dan quitter. Berdasarkan angket adversity quotient untuk mengetahui kategori siswa untuk dipilihkan beberapa subjek untuk mengerjakan soal tes. Siswa yang dipilih adalah siswa berdasarkan kategori adversity quotient yang telah direkomendasi guru dan mampu mengerjakan soal yang diberikan. Kemudian data di analisis menggunakan proses pemecahan masalah berdasarkan tahapan Mason dkk. Data kualitatif yang didapatkan dari analisis hasil pekerjaan siswa dan wawancara semi terstruktur.

Tabel 1. Tingkat Adversity Quotiont Siswa Kelas IX MTsN 1 Kota Bima

\begin{tabular}{|c|c|c|c|c|c|}
\hline Tingkat AQ & Climber & $\begin{array}{c}\text { Peralihan camper } \\
\text { menuju climber }\end{array}$ & Camper & $\begin{array}{c}\text { Peralihan } \\
\text { quitter menuju } \\
\text { camper }\end{array}$ & Quitter \\
\hline Banyaknya siswa & 2 & 32 & 63 & 19 & 3 \\
\hline Persentase & $1,68 \%$ & $26,98 \%$ & $52,94 \%$ & $15,96 \%$ & $2,53 \%$ \\
\hline
\end{tabular}

Berdasarkan hasil perhitungan ARP dibawah ini tabel daftar nama subjek penelitian 
Tabel 2. Daftar Nama Subjek Penelitian

\begin{tabular}{|c|c|c|c|c|}
\hline No & Nama & $\begin{array}{c}\text { Skor } \\
\boldsymbol{A R P}\end{array}$ & Tingkat AQ & Kode \\
\hline 1 & FK & 167 & climber & CL1 \\
\hline 2 & DKR & 169 & climber & CL2 \\
\hline 3 & FDZ & 120 & camper & CA1 \\
\hline 4 & FDA & 112 & camper & CA2 \\
\hline 5 & BP & 58 & quitter & QU1 \\
\hline 6 & YZH & 59 & quitter & QU2 \\
\hline
\end{tabular}

Siswa dengan inisial untuk selanjutnya dikodekan dengan CL1 dan CL2 yaitu subyek penelitian dengan tingkat AQ climber. Siswa dengan inisial untuk selanjutnya dikodekan dengan CA1 dan CA2 yaitu subyek penelitian dengan tingkat AQ camper. Siswa dengan inisial untuk selanjutnya dikodekan dengan QU1 dan QU2 yaitu subyek penelitian dengan tingkat AQ quitter.

Proses pengambilan data dilaksanakan pada rentang waktu hari Jum'at tanggal 27 Agustus 2021 sampi dengan hari Minggu tanggal 31 Oktober 2021. Pelaksanaan bertempat di perpustakaan MTs Negeri 1 Kota Bima. Peneliti meminta subjek mengerjakan lembar soal kemudian dilakukan wawancara setelah subjek mengumpulkan pekerjaannya. Waktu pelaksanaan pengambilan data pada beberapa subjek berbeda.

Analisis yang dilakukan dalam penelitian ini adalah bentuk kesamaan masing-masing tiap kategori adversity quotient yang terdiri dari siswa climber, siswa camper dan siswa quitter dalam hal penyelesaian masalah berdasarkan tahapan Mason dan wawancara yang dilakukan.

Proses Pemecahan Masalah Pada Siswa Kategori Siswa Climber (SC).

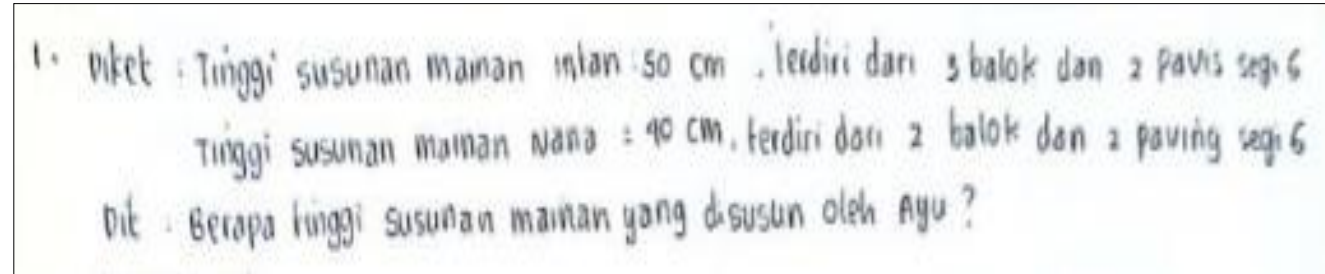

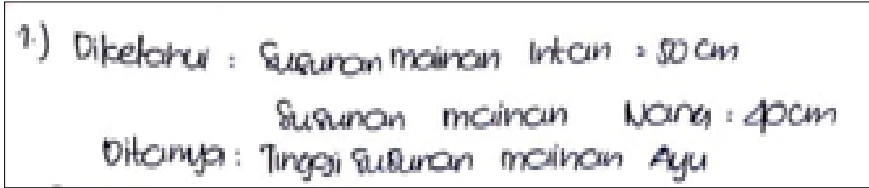

Gambar 2. Hasil Pekerjaan siswa climber pada Masalah

Berdasarkan hasil pekerjaan dan wawancara yang dilakukan pada siswa climber, dimana terdapat kesamaan pada tahapan fase entry peneliti dapat mengetahui bahwa subjek telah memenuhi pada tahapan fase ini. Subjek siswa camper dapat memenuhi rubrik introduce karena merepresentasikan elemen-elemen dengan simbol-simbol dan menyusun yang diketahui pada masalah. Sedangkan untuk rubrik know dan want untuk mengetahuinya dengan melalui wawancara untuk menceritakan perihal masalah yang diberikan, yaitu pernah atau tidaknya subjek mendapatkan 
Proses Pemecahan Masalah Sistem Persamaan Linear Dua Variabel Berdasarkan Tahapan Mason Ditinjau dari Tipe Adversity Quotient, Novi Nurhayati, Subanji, Swasono Rahardjo

soal yang serupa, tentang informasi yang diketahui dan hal yang ditanyakan dari soal tersebut. Berikut wawancara antara peneliti dan siswa climber.

Peneliti $\quad$ : Boleh diceritakan apa yang pertama kali dipikirkan pada saat membaca soal?

SC $\quad$ : Yang pertama adalah membaca soal secara keseluruhan, lalu memahami soal dan yang terakhir mengambil data-data yang dibutuhkan.

Peneliti $\quad$ : Baiklah, apakah pernah menemukan soal seperti ini sebelumnya?

$\mathrm{SC}$

: Iyah pernah Bu.

Berdasarkan wawancara di atas dapat disimpulkan bahwa pada fase entry siswa climber dapat memenuhi rubrik know karena siswa climber memahami masalah dengan baik, hal ini terlihat dari siswa climber mampu mengidentifikasi masalah yang dimiliki pada masalah dan menjelaskan dengan baik terkait informasi yang diketahui dari masalah berdasarkan wawancara yang dilakukan, meskipun siswa camper tidak menuliskannya pada lembar kerja. Berikut wawancara antara peneliti dan siswa climber.

Peneliti : Baiklah, Apa saja fakta-fakta yang Anda ketahui dari soal berdasarkan yang anda tulis terkait yang diketahui dan ditanya?

$\mathrm{SC}$

: Fakta yang ditemukan adalah mencari yang diketahuinya, kemudian melihat gambarnya antara balok dan paving ini, dimana tinggi antara keduannya. Langsung kepikiran bahwa tinggi mereka adalah $50 \mathrm{~cm}$ dan $40 \mathrm{~cm}$. Dengan menentukan tinggi mainan Ayu dan Nana. Kemudian ada mainan yang dibuat oleh Intan terdiri dari 3 balok dan 4 paving dengan tinggi $50 \mathrm{~cm}$. sedang yang dibuat oleh Nana adalah 2 balok dan 3 paving segienam dengan tinggi $40 \mathrm{~cm}$. nah karena ini adalah sistem persamaan linear dua variabel kita memisalkan persamaannya. Dimana balok disimbolkan dengan A dan paving segienam di simbolkan dengan B. Kemudian yang ditanyakan adalah tinggi susunan mainan yang disusun ayu jika terdiri dari 1 balok dan 1 paving segienam adalah berapa.

Peneliti : Untuk menyelesaikan permasalahan tersebut bagaimana caranya?

$\mathrm{SC}$

: Karena ini materi sistem persamaan linear dua variabel, jadi saya menggunakan cara eliminasi dan subtitusi.

Berdasarkan wawancara di atas dapat disimpulkan bahwa pada fase entry siswa climber memenuhi rubrik want karena mampu menentukan apa yang ditanyakan oleh soal. Berdasarkan hasil pekerjaan tertulis siswa climber pada fase attack peneliti dapat mengetahui bahwa subjek memenuhi rubrik try dan why. siswa camper dikatakan mengetahui rubrik try karena subjek mengajukan penyelesaian masalah berupa persamaan yang dibuatnya kemudian mencobanya menyelesaikannya. 


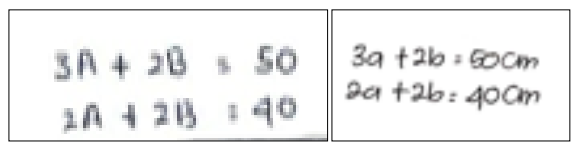

Gambar 3. Jawaban siswa climber pada Masalah

Adapun berikut wawancara yang dilakukan antara peneliti dan siswa climber (SC) terkait dugaan yang dibuat.

Peneliti : Disini kamu mejawab $3 A+2 B=50$ dan $2 A+2 B=40$ itu dapat dari mana?

$\mathrm{SC}$

: Dari yang pertama Intan yaitu memiliki susunan mainan 3 balok dan 2 paving segienam dengan tinggi $50 \mathrm{~cm}$ menjadi bentuk persamaannya adalah $3 A+2 B=50$ dan Nana memiliki susunan mainan balok 2 balok dan 2 paving segienam dengan tinggi $40 \mathrm{~cm}$ maka menjadi $2 A+2 B=40$

Peneliti : Jadi maksud dari tulisan mu itu?

$\mathrm{SC}$

: Nah itu maksudnya persamaan 1 dan persamaan 2

Berdasarkan hasil wawancara yang dilakukan dengan siswa climber mengajukan dugaan penyelesaian masalah terlihat pada hasil wawancara yang dilakukan, meskipun tidak menuliskan secara lengkap pada lembar kerja yang diberikan.

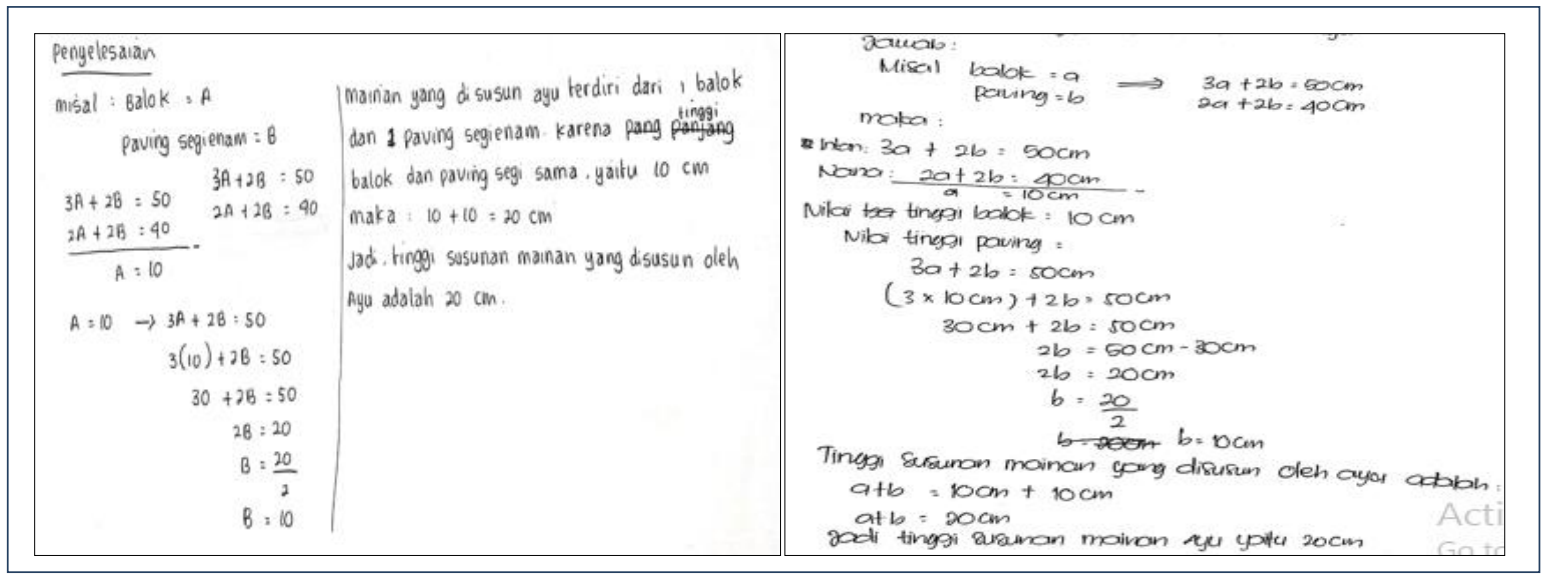

Gambar 4. Jawaban Siswa Climber pada Masalah

Berdasarkan dari hasil pengerjaan yang dilakukan oleh siswa climber, dimana langkah- langkah penyelesaian benar dan hasil jawabanpun benar. Subjek siswa climber dapat dikatakan menyelesaiakan masalah sesuai dengan permintaan soal. Kemudian hal ini juga dibuktikan dengan wawancara yang dilakukan pada siswa climber.

Peneliti : : Coba dijelaskan langkah penyelesaian masalahnya ini seperti apa?

$\mathrm{SC}$

: Pernah yang dilakukan dari kedua persamaan tersebut adalah mengeliminasi yaitu mencoret yang mempunyai nilai yang sama. Kemudian tinggal $3 A$ dan $2 A$, ini dikurangkan hasilnya $1 A$ atau bias dituliskan dengan A saja. Selanjutnya 50 dan 40 dikurangkan hasilnya adalah 10. Jadi hasilnya adalah 10. 
Proses Pemecahan Masalah Sistem Persamaan Linear Dua Variabel Berdasarkan Tahapan Mason Ditinjau dari Tipe Adversity Quotient, Novi Nurhayati, Subanji, Swasono Rahardjo

Peneliti : : Berarti 10 ini adalah nilai dari?

$\mathrm{SC}$

: Dimana 10 ini adalah nilai dari A, A tadi nilainya 1, kemudian $A=\frac{10}{1}$ adalah 10.

Peneliti

: Langkah selanjutnya?

$\mathrm{SC}$

: Dari hasil nilai $A=10$, maka disubtitusikan pada salah satu persamaan. Saya memilih persamaan yang pertama

Peneliti $\quad$ : Kenapa memilih persamaan yang pertama tidak yang persamaan yang kedua?

$\mathrm{SC}$

: Karena pengen saja bu. Sebenarnya sama saja bu, mau persamaan yang pertama atau kedua

Peneliti : Apakah nantinya hasilnya tetap sama?

SC : : Iyah bu tetap sama

Peneliti : Penyelesaian selanjutnya bagaimana?

$\mathrm{SC}$

: Dari nilai $A=10$, kemudian disubtitusikan pada persamaan pertama yaitu $3 A+$ $2 B=50$. Maka $3(10)+2 B=50$, sehingga $30+2 B=50$. Nilai 30 dipindah ruas ke kanan menjadi -30 sehinga $50-20=30$, kemudian menjadi $2 B=20$, selanjutnya $\frac{20}{2}$ maka nilai $B$ menjadi 10 . Karena yang ditanyakan adalah tinggi dari 1 balok dan 1 paving maka nilai $A$ dan $B$ dijumlahkan maka $10+10=20 \mathrm{~cm}$. Jadi tinggi dari susunan mainan yang dibuat ayu adalah $20 \mathrm{~cm}$.

Peneliti : Apakah hasil penyelesaian dari tinggi badan Ayu adalah $20 \mathrm{~cm}$ ?

$\mathrm{SC}$

: Iyah bu

Berdasarkan hasil kerja siswa climber, peneliti menduga bahwa siswa climber memenuhi rubrik check karena tidak terdapat kesalahan pada proses penyelesaian masalah yang dituliskan dan siswa climber melakukan pengecekan terhadap simpulan yang dibuat. Apakah sesuai dengan permintaan soal. Sedangkan pada rubrik reflect dan extend belum diketahui karena tidak tertulis pada hasil kerja objek. Oleh karena itu peneliti mengajukan beberapa pertanyaan terkait kesulitan dalam menyelesaikan masalah dan cara lain yang dipikirkan dalam menyelesaikan masalah tersebut. Berikut wawancara antara peneliti dan siswa climber.

Peneliti : Apakah Anda sudah memeriksa ketepatan perhitungan yang sudah Anda lakukan?

$\mathrm{SC}$

: Sudah bu

Peneliti : : Apakah kamu mengalami kesulitan dalam menyelesaian masalah tersebut?

$\mathrm{SC}$

: Tidak terlalu susah bu, masih bisa untuk dikerjakan

Peneliti $\quad$ : Selain cara itu apakah ada cara lain untuk menyelesaikan masalah tersebut?

$\mathrm{SC}$ : Ada bu dengan eliminasi saja atau subtitusi saja.

Berdasarkan wawancara tersebut dapat disimpulkan bahwa siswa climber tidak memenuhi rubrik refleck pada fase review karena siswa climber tidak mengalami kesulitan dalam menyelesaikan 
masalah tersebut. Selain itu siswa climber memenuhi rubrik extend karena dapat memikirkan cara lain dalam menyelesaikan masalah tersebut. Jadi siswa climber memliki kesamaan yang hampir sama, pada tahapan entry mampu memenuhi rubrik know dengan memahami masalah secara baik, rubrik want mampu mengklasifikasi masalah dan pada rubrik introduce mampu merepresentasikan elemenelemen dalam bentuk simbol-simbol menggunakan $a$ dan $b$. Tahapan attack siswa climber dengan rubric try sama-sama mampu memisalkan kedalam bentuk matematika dari masalah yang diberikan, sedangkan pada rubrik maybe mampu menyelesaikan masalah dengan benar dan pada rubrik why mampu memberikan alasan dan mengkomunikasi hasil penyelesaiannya. Tahapan selanjutnya review siswa camper mampu memenuhi check dengan mengecek kembali perhitungan, rubrik reflect tidak mengalami kesulitan dalam penyelesaian soal dan rubrik extend mampu menyelesaikan dengan cara lain meskipun tidak memuliskan dilembar jawaban siswa. Proses Pemecahan Masalah Pada Siswa Kategori Siswa Camper (SP)

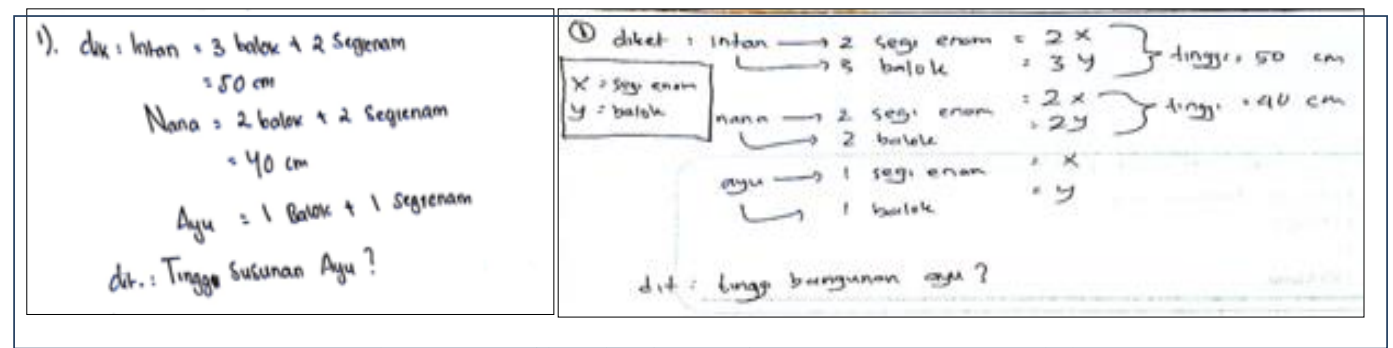

Gambar 7. Hasil Pekerjaan Siswa Camper Masalah

Berdasarkan hasil pekerjaan dan wawancara yang dilakukan pada siswa camper, dimana terdapat kesamaan dalam menuliskan yang diketahui dan ditanyakan pada tahapan fase entry peneliti dapat mengetahui bahwa subjek telah memenuhi pada tahapan fase ini. Subjek siswa camper memenuhi rubrik introduce karena sama-sama merepresentasikan elemen-elemen dengan simbol $x$ dan $y$ dan menyusun yang diketahui pada masalah. Sedangkan untuk rubrik know dan want untuk mengetahuinya dengan melalui wawancara untuk menceritakan perihal masalah, yaitu pernah atau tidaknya subjek mendapatkan soal yang serupa, tentang informasi yang diketahui dan hal yang ditanyakan dari soal tersebut. Berikut wawancara antara peneliti dan siswa camper.

\section{Peneliti $\quad$ : Boleh diceritakan apa yang pertama kali dipikirkan pada saat membaca soal? \\ SP : membaca soal, memahaminya dan menentukan bagaimana cara menyelesaikan permasalahan ini}

Peneliti : : Apakah pernah menemukan soal seperti ini sebelumnya?

SP : Iyah pernah.

Berdasarkan wawancara di atas dapat disimpulkan bahwa pada fase entry siswa camper memenuhi rubrik know karena siswa camper memahami masalah dengan baik, hal ini terlihat dari 
Proses Pemecahan Masalah Sistem Persamaan Linear Dua Variabel Berdasarkan Tahapan Mason Ditinjau dari Tipe Adversity Quotient, Novi Nurhayati, Subanji, Swasono Rahardjo

siswa camper mampu mengidentifikasi masalah yang dimiliki pada masalah berdasarkan wawancara yang dilakukan. Berikut wawancara antara peneliti dan siswa camper.

Peneliti $\quad$ : Baiklah, Apa saja fakta-fakta yang Anda ketahui dari soal berdasarkan yang anda tulis terkait yang diketahui dan ditanya?

SP

: Diketahui susunan balok mainan Intan itu terdiri dari 3 balok sama dua segienam dengan total tinggi $50 \mathrm{~cm}$. sedangkan susunan mainan Nana itu 2 balok dan 2 segienam dengan total tinggi $40 \mathrm{~cm}$ dan juga diketahui susunan mainan Ayu adalah 1 balok dan 1 segienam, kemudian ditanyakan adalah tinggi susunan mainan Ayu.

Peneliti : Untuk menyelesaikan permasalahan tersebut bagaimana caranya?

SP : saya menggunakan cara campuran yaitu eliminasi dan subtitusi

Berdasarkan wawancara di atas dapat disimpulkan bahwa pada fase entry siswa camper memenuhi rubrik want karena mampu menentukan apa yang ditanyakan oleh soal. Pada hasil pekerjaan tertulis siswa camper pada fase attack peneliti dapat mengetahui bahwa subjek memenuhi rubrik try dan why. Siswa camper dikatakan mengetahui rubrik try karena subjek mengajukan penyelesaian masalah berupa persamaan yang dibuatnya kemudian mencobanya menyelesaikannya, tetapi tidak menuliskan terlebih dugaaan penyelesaian secara terpisah agar memudahkan orang lain untuk memahami tetapi langsung menuliskan dengan bentuk penyelesaiannya. Adapun berikut wawancara yang dilakukan antara peneliti dan siswa camper terkait dugaan yang dibuat.

Peneliti $\quad$ : Bentuk persamaan yang dituliskan ini ya? (menunjuk persamaan siswa)

SP

: Iyah bu ini. Saya menuliskannya secara langsung dihitungannya

Peneliti : Kenapa tidak menuliskan bentuk persamaannya terlebih dahulu kemudian persamaan ke bentuk penyelesaiannya?

SP

: Biar cepat bu

Berdasarkan hasil wawancara yang dilakukan siswa camper mengajukan dugaan penyelesaian masalah kemudian langsung pada pengerjaan penyelesaiannya, ini terlihat pada hasil wawancara yang dilakukan.

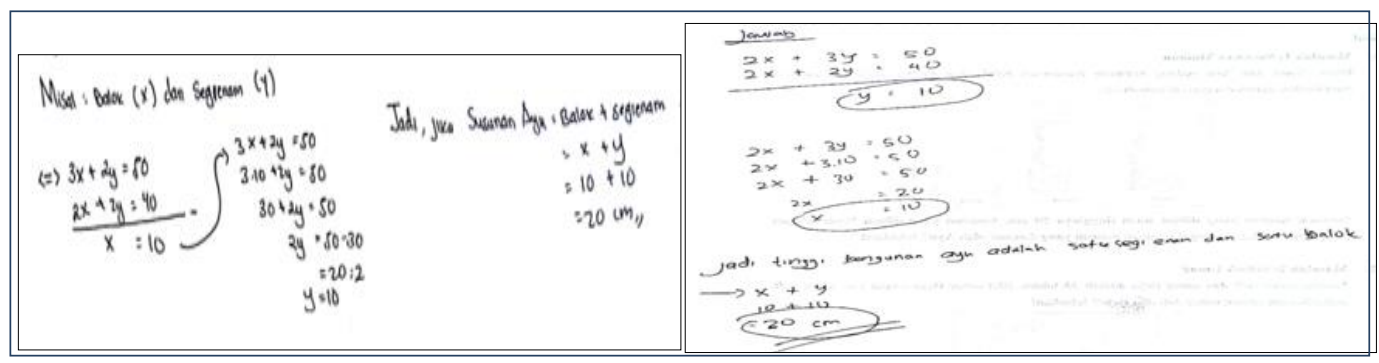

Gambar 8. Jawaban Siswa Camper pada Masalah 
Berdasarkan dari hasil pengerjaan yang dilakukan oleh siswa camper, dimana langkah- langkah penyelesaian benar dan hasil jawabanpun benar. Subjek siswa camper dapat dikatakan menyelesaiakan masalah sesuai dengan permintaan soal. Kemudian hal ini juga dibuktikan dengan wawancara yang dilakukan pada siswa camper.

Peneliti : Bagaimana langkah penyelesaianya?

SP

: Karena diketahui susunan balok mainan Intan itu terdiri dari 3 balok sama dua segienam dengan total tinggi $50 \mathrm{~cm}$. sedangkan susunan mainan Nana itu 2 balok dan 2 segienam dengan total tinggi $40 \mathrm{~cm}$. kita misalkan terlebih dahulu balok adalah $x$ dan segienam adalah $y$. Jadi dimasukkan kedalam bentuk persamaannya susunan mainan Intan dan Nana yaitu $3 x+2 y=50$ dan $2 x+2 y=40$. Kedua persamaan tersebut dieliminasikan karena $2 y$ pada persamaan pertama dan kedua sama maka langsung dicoret maka menjadi $x=10$. Kemudian mengambil salah satu persamaan untuk mencari nilai y. Disini saya mengambil persamaan yang pertama

Peneliti : : Kenapa memilih persamaan yang pertama

SP $\quad$ : Saya diajarkan dulu menggunakan persamaan yang pertama

Peneliti : Kemudian langkah selanjutnya?

SP

:Memasukkan nilai $x=10$ pada persamaan yang pertama yaitu $3 \cdot 10+2 y=$ 50 sehingga menghasilkan nilai $y=10$. Karena yang ditanyakan adalah 1 balok ditambah 1 segienam atau $x$ di tambah y maka menghasilkan $20 \mathrm{~cm}$.

Berdasarkan hasil kerja siswa camper (SP), peneliti menduga bahwa siswa camper memenuhi rubrik check karena tidak terdapat kesalahan pada proses penyelesaian masalah yang dituliskan dan siswa camper melakukan pengecekan terhadap simpulan yang dibuat. Apakah sesuai dengan permintaan soal. Sedangkan pada rubrik reflect dan extend belum diketahui karena tidak tertulis pada hasil kerja objek. Oleh karena itu peneliti mengajukan beberapa pertanyaan terkait kesulitan dalam menyelesaikan masalah dan cara lain yang dipikirkan dalam menyelesaikan masalah tersebut. Berikut wawancara antara peneliti dan siswa camper.

Peneliti : Apakah Anda sudah memeriksa ketepatan perhitungan yang sudah Anda lakukan?

SP

: Sudah bu

Peneliti : : Apakah kamu mengalami kesulitan dalam menyelesaian masalah tersebut?

SP : : Tidak terlalu susah bu, masih bisa untuk dikerjakan

Peneliti : Selain cara itu apakah ada cara lain untuk menyelesaikan masalah tersebut?

SP : : Tidak tau bu.

Berdasarkan wawancara tersebut dapat disimpulkan bahwa siswa camper tidak memenuhi rubrik refleck pada fase review karena siswa camper tidak mengalami kesulitan dalam menyelesaikan 
Proses Pemecahan Masalah Sistem Persamaan Linear Dua Variabel Berdasarkan Tahapan Mason Ditinjau dari Tipe Adversity Quotient, Novi Nurhayati, Subanji, Swasono Rahardjo

masalah tersebut. Selain itu siswa camper memenuhi rubrik extend karena tidak dapat memikirkan cara lain dalam menyelesaikan masalah tersebut. Siswa siswa camper juga tidak menuliskan kesimpulan pada akhir soal. Jadi siswa camper memliki kesamaan, pada tahapan entry mampu memenuhi rubrik know dengan memahami masalah secara baik, rubrik want mampu mengklasifikasi masalah dan pada rubrik introduce mampu merepresentasikan elemen-elemen dalam bentuk simbolsimbol menggunakan $x$ dan $y$. Tahapan attack siswa camper dengan rubric try sama-sama mampu memisalkan kedalam bentuk matematika meskipun tidak menuliskan secara lengkpa pada lembar jawabannya, sedangkan pada rubrik maybe mampu menyelesaikan masalah dengan benar dan pada rubrik why mampu memberikan alasan dan mengkomunikasi hasil penyelesaiannya. Tahapan selanjutnya review siswa camper tidak mampu memenuhi check karena tidak mengecek kembali perhitungan dan ketepatan penyelesaiaannya, rubrik reflect tidak mengalami kesulitan dalam penyelesaian soal dan rubrik extend tidak mampu menyelesaikan dengan cara lain. Proses Pemecahan Masalah Pada Siswa Quitter (SC)

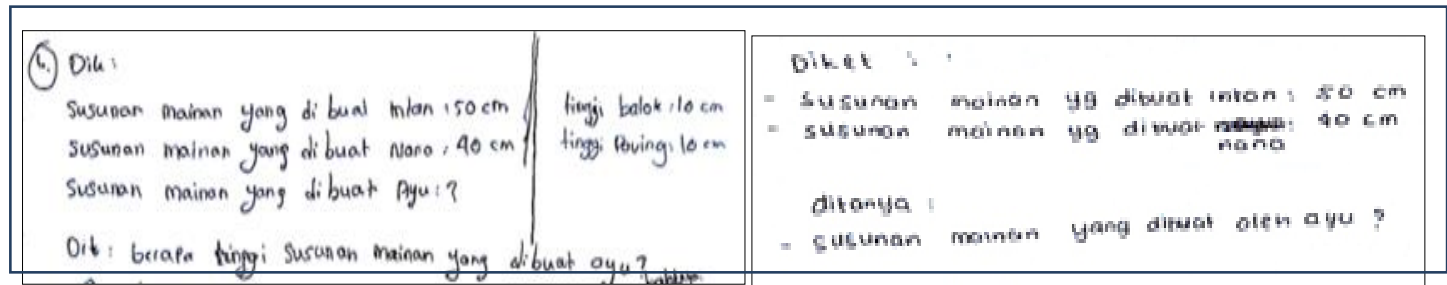

Gambar 11. Hasil Pekerjaan Siswa Quitter

Berdasarkan hasil pekerjaan dan wawancara yang dilakukan pada siswa quitter, dimana pada tahapan fase entry peneliti dapat mengetahui bahwa subjek tidak memenuhi pada tahapan fase ini. Subjek siswa quitter tidak memenuhi rubrik introduce karena tidak dapat merepresentasikan elemenelemen dengan simbol- simbol dan menyusun yang diketahui pada masalah. Sedangkan untuk rubrik know dan want untuk mengetahuinya dengan melalui wawancara untuk menceritakan perihal masalah, yaitu pernah atau tidaknya subjek mendapatkan soal yang serupa, tentang informasi yang diketahui dan hal yang ditanyakan dari soal tersebut. Berikut wawancara antara peneliti dan siswa quitter.

Peneliti $\quad$ : Boleh diceritakan apa yang pertama kali dipikirkan pada saat membaca soal?

SQ

: Mencari apa yang diketahui dari soal untuk menentukan apa yang ditanyakan

Peneliti : : Oke. Pernah melihat soal yang seperti ini sebelumnya?

SQ

: Mungkin pernah.

Berdasarkan wawancara di atas dapat disimpulkan bahwa pada fase entry siswa quitter tidak memenuhi rubrik know karena siswa quitter tidak memahami masalah, hal ini terlihat dari siswa quitter tidak mampu mengidentifikasi masalah yang dimiliki pada masalah berdasarkan wawancara. Berikut wawancara antara peneliti dan siswa quitter. 
Peneliti : Apa saja fakta-fakta yang Anda ketahui dari soal berdasarkan yang anda tulis terkait yang diketahui dan ditanya?

SQ

: Diketahui ini adalah susunan yang dibuat Intan adalah $50 \mathrm{~cm}$ dan susunan mainan yang dibuat Nana adalah $40 \mathrm{~cm}$. kemudian yang ditanyakan adalah susunan yang dibuat oleh Ayu.

Peneliti : Hanya itu saja?

SQ $\quad:$ Iyah bu

Peneliti : Penyelesaiannya masalahnya ini menggunakan cara apa?

SQ $\quad$ : Menggunakan logika bu.

Berdasarkan wawancara di atas dapat disimpulkan bahwa pada fase entry siswa quitter tidak memenuhi rubrik want karena tidak mampu menentukan apa yang ditanyakan oleh soal. Berdasarkan hasil pekerjaan tertulis siswa quitter pada fase attack peneliti dapat mengetahui bahwa subjek tidak memenuhi rubrik try dan why. siswa quitter dikatakan tidak memenuhi rubrik try karena subjek tidak mengajukan penyelesaian masalah berupa persamaan yang dibuatnya kemudian mencobanya menyelesaikannya.

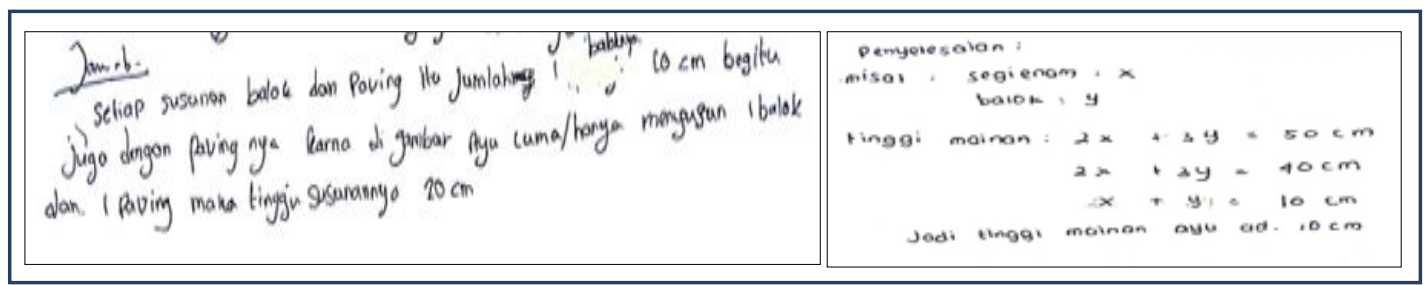

Gambar 12. Hasil Pekerjaan Siswa Quitter

Adapun berikut wawancara yang dilakukan antara peneliti dan subjek siswa quitter terkait dugaan yang dibuat pada masalah.

Peneliti $\quad$ : Coba dijelaskan langkah penyelesaian masalahnya ini seperti apa?

SQ

: Ini adalah Ayu dan Nana menyusun balok dan paving segienam, jadi diketahui 1 balok itu adalah tinggi $10 \mathrm{~cm}$, kemudian menurut logika saya ini paving tingginya 10 cm dan susunan yang disusun sama intan ini ada 3 balok sama 2 paving jadi tingginya $50 \mathrm{~cm}$ sedangkan Nana adalah 2 balok dan 2 paving dengan tinggi $40 \mathrm{~cm}$. Jadi gambar yang saya lihat itu Ayu cuman 1 balok 1 paving jadi jawabannya adalah $20 \mathrm{~cm}$.

Peneliti : Apa yang dapat kamu simpulkan dari penyelesaian soal tersebut?

SQ

: Jadi kesimpulannya adalah tinggi mainan yang dibuat Ayu adalah $20 \mathrm{~cm}$

Peneliti : : Apakah kesimpulan yang kamu peroleh sudah benar sesuai dengan permasalahan soal? 
Proses Pemecahan Masalah Sistem Persamaan Linear Dua Variabel Berdasarkan Tahapan Mason Ditinjau dari Tipe Adversity Quotient, Novi Nurhayati, Subanji, Swasono Rahardjo

Berdasarkan hasil kerja siswa quitter, peneliti menilai bahwa subjek siswa quitter tidak memenuhi rubrik check karena terdapat kesalahan pada proses penyelesaian masalah yang dituliskan dan siswa quitter tidak melakukan pengecekan terhadap simpulan yang dibuat. Apakah sesuai dengan permintaan soal. Sedangkan pada rubrik reflect dan extend belum diketahui karena tidak tertulis pada hasil kerja objek. Oleh karena itu peneliti mengajukan beberapa pertanyaan terkait kesulitan dalam menyelesaikan masalah dan cara lain yang dipikirkan dalam menyelesaikan masalah tersebut. Berikut wawancara antara peneliti dan siswa quitter.

Peneliti : Apakah Anda sudah memeriksa ketepatan perhitungan yang sudah Anda lakukan?

SQ

: Sudah bu

Peneliti : Apakah kamu mengalami kesulitan dalam menyelesaian masalah tersebut?

SQ

: Sudah lupa bu cara mengerjakannya

Peneliti

: Selain cara itu apakah ada cara lain untuk menyelesaikan masalah tersebut?

SQ

: Tidak tau bu.

Berdasarkan wawancara tersebut dapat disimpulkan bahwa siswa quitter tidak memenuhi rubrik refleck pada fase review karena siswa quitter mengalami kesulitan dalam menyelesaikan masalah tersebut. Selain itu siswa quitter tidak memenuhi rubrik extend karena dapat memikirkan cara lain dalam menyelesaikan masalah tersebut. Berikut dibawah ini Tabel 3. kesamaan proses pemecahan masalah berdasarkan tahapan mason ditinjau dari Adversity Quotient

Tabel 3. Kesamaan Proses Pemecahan Masalah berdasarkan Tahapan Mason

\begin{tabular}{|c|c|c|c|c|c|c|c|}
\hline \multirow{2}{*}{$\begin{array}{l}\text { Tahapan } \\
\text { dan } \\
\text { Rubrik }\end{array}$} & \multirow{2}{*}{$\begin{array}{l}\text { Kode } \\
\text { Indik- } \\
\text { ator }\end{array}$} & \multicolumn{2}{|c|}{ Climber } & \multicolumn{2}{|c|}{ Camper } & \multicolumn{2}{|c|}{ Quitter } \\
\hline & & CL1 & CL2 & CA1 & CA2 & QU1 & QU2 \\
\hline \multicolumn{8}{|l|}{ Entry } \\
\hline Know & K1 & \multicolumn{2}{|c|}{$\begin{array}{l}\text { Mampu memahami masalah } \\
\text { dengan seksama, dibuktikan } \\
\text { dari hasil wawancara dan } \\
\text { jawaban tes tulis. }\end{array}$} & \multicolumn{2}{|c|}{$\begin{array}{l}\text { Mampu memahami } \\
\text { masalah dengan } \\
\text { seksama, dibuktikan dari } \\
\text { hasil wawancara dan } \\
\text { jawaban tes tulis }\end{array}$} & \multicolumn{2}{|c|}{$\begin{array}{l}\text { Mampu memahami masalah } \\
\text { dengan seksama, dibuktikan } \\
\text { dari hasil wawancara dan } \\
\text { jawaban tes tulis }\end{array}$} \\
\hline \multirow[t]{2}{*}{ Want } & W1 & \multicolumn{2}{|c|}{$\begin{array}{l}\text { Mampu mengklasifikasikan dan } \\
\text { menyaring informasi dengan } \\
\text { tepat }\end{array}$} & \multicolumn{2}{|c|}{$\begin{array}{l}\text { Mampu } \\
\text { mengklasifikasikan dan } \\
\text { menyaring informasi } \\
\text { dengan tepat }\end{array}$} & \multicolumn{2}{|c|}{$\begin{array}{l}\text { Tidak mampu } \\
\text { mengklasifikasikan dan } \\
\text { menyaring informasi dengan } \\
\text { tepat }\end{array}$} \\
\hline & $\mathrm{W} 2$ & \multicolumn{2}{|c|}{$\begin{array}{l}\text { Mampu menentukan apa yang } \\
\text { ditanyakan pada masalah } \\
\text { dengan baik }\end{array}$} & \multicolumn{2}{|c|}{$\begin{array}{l}\text { Mampu menentukan apa } \\
\text { yang ditanyakan pada } \\
\text { masalah dengan baik }\end{array}$} & \multicolumn{2}{|c|}{$\begin{array}{l}\text { Tidak mampu menentukan } \\
\text { apa yang ditanyakan pada } \\
\text { masalah dengan baik }\end{array}$} \\
\hline $\begin{array}{c}\text { Introduc } \\
e\end{array}$ & I1 & \multicolumn{2}{|c|}{$\begin{array}{l}\text { Mampu merepresentasikan } \\
\text { elemen-elemen penting dalam } \\
\text { bentuk simbol permisalan } \\
\text { persamaan dengan } A \text { dan } B\end{array}$} & \multicolumn{2}{|c|}{$\begin{array}{l}\text { Mampu } \\
\text { merepresentasikan } \\
\text { elemen-elemen penting } \\
\text { dalam bentuk simbol } \\
\text { permisalan persamaan } \\
\text { dengan } x \text { dan } y\end{array}$} & \multicolumn{2}{|c|}{$\begin{array}{l}\text { Tidak mampu } \\
\text { merepresentasikan elemen- } \\
\text { elemen penting dalam } \\
\text { bentuk gambar, diagram, } \\
\text { simbol dan tabel. }\end{array}$} \\
\hline \multicolumn{8}{|l|}{ Attack } \\
\hline Try & $\mathrm{T} 1$ & \multicolumn{2}{|c|}{$\begin{array}{l}\text { Mampu mengajukan dugaan } \\
\text { penyelesaian masalah dengan }\end{array}$} & \multicolumn{2}{|c|}{$\begin{array}{l}\text { Mampu mengajukan } \\
\text { dugaan penyelesaian }\end{array}$} & \multicolumn{2}{|c|}{$\begin{array}{l}\text { Tidak mampu mengajukan } \\
\text { dugaan penyelesaian }\end{array}$} \\
\hline
\end{tabular}




\begin{tabular}{|c|c|c|c|c|}
\hline & & benar & masalah dengan benar & masalah dengan benar \\
\hline Maybe & M1 & $\begin{array}{l}\text { Mampu mencoba dugaan yang } \\
\text { telah dibuat untuk } \\
\text { menyelesaiakan masalah }\end{array}$ & $\begin{array}{l}\text { Mampu mencoba dugaan } \\
\text { yang telah dibuat untuk } \\
\text { menyelesaiakan masalah }\end{array}$ & $\begin{array}{l}\text { Tidak mampu mencoba } \\
\text { dugaan yang telah dibuat } \\
\text { untuk menyelesaiakan } \\
\text { masalah }\end{array}$ \\
\hline Why & H1 & $\begin{array}{l}\text { Mampu mengomunikasikan } \\
\text { alasan tersebut untuk } \\
\text { menyakinkan orang lain baik } \\
\text { lisan maupun tulisan dengan } \\
\text { penyajikan penyelesaian } \\
\text { masalah secara sistematis }\end{array}$ & $\begin{array}{l}\text { Mampu } \\
\text { mengomunikasikan } \\
\text { alasan tersebut untuk } \\
\text { menyakinkan orang lain } \\
\text { baik lisan maupun } \\
\text { tulisan dengan } \\
\text { penyajikan penyelesaian } \\
\text { masalah secara } \\
\text { sistematis }\end{array}$ & $\begin{array}{l}\text { Tidak mampu } \\
\text { mengomunikasikan alasan } \\
\text { tersebut untuk menyakinkan } \\
\text { orang lain baik lisan } \\
\text { maupun tulisan dengan } \\
\text { penyajikan penyelesaian } \\
\text { masalah secara sistematis }\end{array}$ \\
\hline \multicolumn{5}{|l|}{ Review } \\
\hline \multirow{2}{*}{ Check } & $\mathrm{C} 1$ & $\begin{array}{l}\text { Mengecek kembali ketepatan } \\
\text { perhitungan yang dilakukan }\end{array}$ & $\begin{array}{l}\text { Tidak mengecek kembali } \\
\text { ketepatan perhitungan } \\
\text { yang dilakukan karena } \\
\text { terburu-buru }\end{array}$ & $\begin{array}{l}\text { Tidak mengecek ketepatan } \\
\text { perhitungan yang dilakukan }\end{array}$ \\
\hline & $\mathrm{C} 2$ & $\begin{array}{l}\text { Dapat mengecek kesesuaian } \\
\text { langkah penyelesaian dengan } \\
\text { pertanyaan }\end{array}$ & $\begin{array}{l}\text { Tidak mengecek } \\
\text { kesesuaian langkah } \\
\text { penyelesaian dengan } \\
\text { pertanyaan }\end{array}$ & $\begin{array}{l}\text { Mengecek kesesuaian } \\
\text { langkah penyelesaian } \\
\text { dengan pertanyaan }\end{array}$ \\
\hline Reflect & R1 & $\begin{array}{l}\text { Mampu Merefleksikan ide } \\
\text { dalam penyelesaian, bagian } \\
\text { mana yang sulit dan apa yang } \\
\text { dapat dipelajari dari } \\
\text { penyelesaian yang dilakukan }\end{array}$ & $\begin{array}{l}\text { Tidak Merefleksikan ide } \\
\text { dalam penyelesaian, } \\
\text { bagian mana yang sulit } \\
\text { dan apa yang dapat } \\
\text { dipelajari dari } \\
\text { penyelesaian yang } \\
\text { dilakukan }\end{array}$ & $\begin{array}{l}\text { Tidak Merefleksikan ide } \\
\text { dalam penyelesaian, bagian } \\
\text { mana yang sulit dan apa } \\
\text { yang dapat dipelajari dari } \\
\text { penyelesaian yang } \\
\text { dilakukan }\end{array}$ \\
\hline Extend & E1 & $\begin{array}{l}\text { Mampu mengungkapkan } \\
\text { mencari cara penyelesaian lain }\end{array}$ & $\begin{array}{l}\text { Tidak mampu mencari } \\
\text { cara penyelesaian lain }\end{array}$ & $\begin{array}{l}\text { Tidak mampu mencari cara } \\
\text { penyelesaian lain }\end{array}$ \\
\hline
\end{tabular}

Bersumber dari ketiga paparan paparan diatas, dimana setiap kategori adversity quetiont climber, camper dan quitter memiliki kemampuan pemecahan masalah yang berbeda (Juwita et al., 2020; Fauziah et al., 2020; Hulaikah et al., 2020). Pada siswa climber mampu memenuhi tahapan Mason yang terdiri dari fase entry, attack dan review dalam proses pemecahan masalah materi sistem persamaan linear dua variabel. Hal ini sesuai dengan penelitian yang dilakukan oleh Sudarman (2008), Widyastuti et al (2017), dan Muna \& Mubarokah (2014) menyatakan bahwa siswa climber mampu memahami masalah dengan baik, menuliskan dengan tepat apa yang diketahui dan apa yang ditanyakan dalam soal dan selalu mengecek kembali hasil yang sudah didapatkan dan mampu menarik kesimpulan dari penyelesaian yang sudah didapatkan, mampu menyusun rencana penyelesaian masalah dengan membuat pengandaian yang mengggunakan variabel, simbol-simbol persamaan linier dan model matematika.

Siswa camper dalam tahapan Mason terdapat rubrik yang tidak terpenuhi yaitu tidak menuliskan pengajuan masalah tersendiri dan tidak menuliskan kesimpulan akhir secara lengkap. Hal ini sesuai bahwa camper sudah puas dengan apa yang dicapainya saat ini dan kurang suka dengan tantangan (Stoltz, 2000). Pendapat serupa dikemukakan oleh Sudarman (2008) menyatakan bahwa siswa camper tidak mau memaksimalkan usahanya, sekedarnya saja dan tidak punya target nilai yang 
Proses Pemecahan Masalah Sistem Persamaan Linear Dua Variabel Berdasarkan Tahapan Mason Ditinjau dari Tipe Adversity Quotient, Novi Nurhayati, Subanji, Swasono Rahardjo

tinggi. Sedangkan siswa quitter mampu memahami masalah dan dalam menyelesaikan masalah belum mampu memenuhi semua ketiga tahapan Mason dalam proses pemecahan masalah entry, attack, dan review. Hal ini menunjukkan bahwa siswa quitter mudah menyerah, dan memilih mundur atau berhenti jika menghadapi kesulitan daripada harus berusaha sekuat tenaga. Dengan demikian bahwa siswa quitter memiliki motivasi yang sangat kurang, ketika mereka menemukan sedikit kesulitan dalam menyelesaikan soal matematika mereka akan langsung menyerah dan berhenti (Suryaningrum et al., 2020).

\section{KESIMPULAN}

Berdasarkan dari hasil penelitian dan pembahasan untuk proses pemecahan masalah siswa pada ketegori adversity quetiont yang terdiri dari climber, camper dan quitter. Siswa climber memenuhi tahapan Mason, dimana pada fase entry memenuhi ketiga rubrik terdiri dari know, want dan introduce. Pada fase attack siswa climber mampu memenuhi rubrik try, maybe dan why. Kemudian fase review dapat memenuhi rubrik check, reflect dan extend. Kemudian Siswa camper terdapat tahapan Mason yang tidak terpenuhi yaitu pada bagian rubrik try karena tidak menuliskan secara lengkap dugaan atau persamaan yang dituliskan dan rubrik review siswa tidak menuliskan kesimpulan akhir dari penyelesaian. Sedangkan siswa quitter hanya mampu memahami masalah dan tidak mampu menyelesaikan permasalahan yang diberikan sehingga pada tahapan Mason tidak terpenuhi. Dengan demikian proses pemecahan masalah ditinjau dari adversity quotient climber, camper dan quitter berbeda-beda pada materi sistem persamaan linear dua variabel.

\section{UCAPAN TERIMAKASIH}

Peneliti mengucapakan terima kasih kepada Kepala Sekolah MTs Negeri 1 Kota Bima. Peneliti telah diberikan kesempatan untuk melaksanakan penelitian dalam rangka untuk menyusun karya ilmiah ini. Tidak lupa juga peneliti mengucapkan terima kasih kepada Dr. Subanji, M.Si. dan Dr. Swasono Rahardjo, M.Si yang telah membimbing peneliti hingga dapat terselesaikannya artikel ilmiah ini. Selain itu, peneliti juga mengucapkan terima kasih kepada semua pihak yang telah membantu.

\section{REFERENSI}

Adnyani, L. P. W., Kurniawan, I., \& Pinahayu, E. A. R. (2018). Development of Creative-Thinking Instrument in Mathematics Problem Solving Based on Logical Mathematics Intelligence. JRAMathEdu (Journal of Research and Advances in Mathematics Education), 3(1), 1. https://doi.org/10.23917/jramathedu.v3i1.5201

Agustini, D., \& Pujiastuti, H. (2020). Analisis Kesulitan Siswa Berdasarkan Kemampuan Pemahaman Matematis dalam Menyelesaikan Soal Cerita Pada Materi SPLDV. Jurnal Media Pendidikan Matematika, 8(1).

Anderson, J. (2009). Mathematics Curriculum Development and the Role of Problem Solving. In 
ACSA Conference, 1-8.

Barham, A. I. (2020). Investigating the development of pre-service teachers' problem-solving strategies via problem-solving mathematics classes. European Journal of Educational Research, 9(1), 129-141. https://doi.org/10.12973/eu-jer.9.1.129

Bautista, M. J. C. (2015). Adversity Quotient and Teaching Performance of Faculty Members. 5(3), $1-6$.

Cai, J. (2003). Singaporean Student's Mathematical Thingking in Problem Solving nnd Problem Posing: An Exploratory Study. International Journal of Mathematical of Education in Science and Technology, 34(5), 719-737.

Chin, P.-L., \& Hung, M.-L. (2013). Psychological Contract Breach and Turnover Intention: The Moderating Roles of Adversity Quotient and Gender. Scientific Journal Publishers, 41(5), 843 859.

Depdiknas. (2006). Standar Kompetensi dan kompetensi dasar tingkat SD, MI, dan SDLB. Depdiknas.

Fauzi, A. M., \& Noviartati, K. (2018). Pengaruh Model Pembelajaran Quantum Teaching Tipe Tandur Ditinjau Dari Motivasi Belajar Siswa. Jurnal Elektronik Pembelajaran Matematika, 5(3), $240-248$.

Fauziah, M., Marmoah, S., Murwaningsih, T., \& Saddhono, K. (2020). European Journal of Educational Research. European Journal of Educational Research Volume, 9(2), 537-568. https://doi.org/10.12973/eu-jer.9.2.537

Febriana, E. (2018). Analisis Kemampuan Pemecahan Masalah Ditinjau dari Kepercayaan Diri Siswa Kelas XI Pada Materi Program Linier.

Gok, T. (2014). Students' achievement, skill and confidence in using stepwise problem-solving strategies. Eurasia Journal of Mathematics, Science and Technology Education, 10(6), 617-624. https://doi.org/10.12973/eurasia.2014.1223a

Gözde, A. (2020). Non-routine problem solving performances of mathematics teacher candidates. Educational Research and Reviews, 15(5), 214-224. https://doi.org/10.5897/err2020.3907

Harahap, R., Dewi, I., \& Sumarno. (2012). Perbedaan Peningkatan Kemampuan Komunikasi dan Koneksi Matematis Siswa Melalui Pembelajaran Kontekstual dengan Kooperatif Tipe STAD di SMP Al-Washliyah 8 Medan. Jurnal Pendidikan Matematika PARADIKMA, 5(2), 186-204.

Hulaikah, M., Degeng, I. N. S., Sulton, \& Murwani, F. D. (2020). The effect of experiential learning and adversity quotient on problem solving ability. International Journal of Instruction, 13(1), 869-884. https://doi.org/10.29333/iji.2020.13156a

Jiang, R., Liu, R. de, Star, J., Zhen, R., Wang, J., Hong, W., Jiang, S., Sun, Y., \& Fu, X. (2021). How mathematics anxiety affects students' inflexible perseverance in mathematics problem-solving: Examining the mediating role of cognitive reflection. British Journal of Educational Psychology, 91(1), 237-260. https://doi.org/10.1111/bjep.12364

Juwita, H. R., Roemintoyo, \& Usodo, B. (2020). International Journal of Educational Methodology 
Proses Pemecahan Masalah Sistem Persamaan Linear Dua Variabel Berdasarkan Tahapan Mason Ditinjau dari Tipe Adversity Quotient, Novi Nurhayati, Subanji, Swasono Rahardjo

The Role of Adversity Quotient in the Field of Education: A Review of the Literature on Educational Development. International Journal of Educational Methodology, 6(3), 507-515. https://doi.org/10.12973/ijem.6.3.507

Karatas, I., \& Baki, A. (2013). The Effect of Learning Environments Based on Problem Solving on Students 'Achievements of Problem Solving. International Electronic Journal of Elementary Education, 5(3), 249-267.

Maimunah, Purwanto, Sa'dijah, C., \& Sisworo. (2016). Penerapan Model Pembelajaran Matematika Melalui Pemecahan Masalah untuk Meningkatkan Penalaran Matematis Siswa Kelas X-A SMA AL-Musilum. Jurnal Review Pembelajaran Matematika, 1(1), 17-30.

Mason, J., Burton, L., \& Stacey, K. (2010). Thinking Mathematically. Pearson Education.

MZ, Z. A., Risnawati, R., Kurniati, A., \& Prahmana, R. C. I. (2017). Adversity Quotient in Mathematics Learning (Quantitative Study on Students Boarding School in Pekanbaru). International Journal on Emerging Mathematics Education, 1(2), 169. https://doi.org/10.12928/ijeme.v1i2.5780

Parvathy, D. U., \& M, P. (2014). Relationship between Adversity Quotient and Academic Problems among Student Teachers. IOSR Journal of Humanities and Social Science, 19(11), 23-26. https://doi.org/10.9790/0837-191172326

Phoolka, E. S., \& Kaur, N. (2012). ADVERSITY QUOTIENT: A New Paradigm in Management to Explore. The International Journal's : Research Journal of Social Science and Management, 3(4), 67-79. www.theinternationaljournal.org

Polya, G. (1981). Mathematical discovery on Understanding. Learning and Teaching Problem Solving. John Willey \& Sons.

Reif, F., \& Heller, J. I. (1982). Knowledge structure and problem solving in physics. Educational Psychologist, 17(2), 17(2), 102-127.

Şimşek, İ., Uygun, T., \& Güner, P. (2020). Problem Solving Performance And Mathematics Achievement: The Mediating Role Of Eye Tracking. International Online Journal of Education and Teaching (IOJET), 7(3), 1111-1124.

Stoltz, P (2000). Adversity Quotient: Mengubah Hambatan Menjadi Peluang (T. Hermaya (ed.)). Grasindo.

Suarsana, I. M., Lestari, I. A. P. D., \& Mertasari, N. M. S. (2019). The effect of online problem posing on students' problem-solving abilitiy in mathematics. International Journal of Instruction, 12(1), 809-820. https://doi.org/10.29333/iji.2019.12152a

Sudarman. (2008). Pembangkit Motivasi Siswa dalam Belajar Matematika. 36-40.

Suryaningrum, C. W., Purwanto, Subanji, Susanto, H., Ningtyas, Y. D. W. K., \& Irfan, M. (2020). Semiotic reasoning emerges in constructing properties of a rectangle: A study of adversity quotient. Journal on Mathematics Education, 11(1), 95-110. https://doi.org/10.22342/jme.11.1.9766.95-110 
Susanto, A. (2015). Teori Belajar Dan Pembelajaran Disekolah Dasar. Prenada Media.

Wahyudi, \& Dewi, A. (2016). Analisis Kemampuan Menyelesaikan Soal Cerita Matematika Tentang

Bangun Datar Ditinjau Dari Teori Van Hiele. Seminar Nasional Matematika X Universitas Negeri Semarang 2016, 481-494.

Widyastuti, R., Usodo, B., \& Riyadi. (2017). Proses Berpikir Siswa Smp Dalam Menyelesaikan Masalah Matematika Berdasarkan Langkah- Langkah Polya. Jurnal Universitas Sebelas Maret Surakarta, 1(3), 239-249.

Yulaelawati, E. (2004). Kurikulum dan Pembelajaran: Filosofi Teori dan Aplikasi. Pakar Raya. 